\title{
The Body as Situation: A Darwinian Reading of The Second Sex
}

\section{By Tone Bleie}

\begin{abstract}
Challenging the influential view that the chapter on biology in the first volume of The Second Sex is exposing scientific myths in severe prose, in the view of this paper, the chapter is as much about scientific facts as it is an intriguingly open-ended dialogue between phenomenology and science. Beauvoir's consuming epistemological and scientific preoccupation with the category of biology is analysed in a bid to advance a new, naturalist-feminist conception of Beauvoir's theory of natural history. The analysis unravels the theoretical edifice, with its tensions between Beauvoir's selective but brilliant appropriation of recent discoveries in evolutionary biology and genetics and certain deliberate rejections and omissions of Darwinian evolutionary thinking. Contrary to Beauvoir's intentions, she ends up conflating the term biology with, in particular, reproductive physiology, and perpetuating the ill-fated division between body and psyche. In contributing to a reformulation of an empirically grounded approach to the embodied mind and situated body, this paper debates some promising insights from contemporary neuroscience and primatology. These insights are critical to theory development, based on a non-anthropocentric stance and non-dualistic understanding of the mind-brain continuum and the body as a situation.
\end{abstract}

\section{Keywords}

Beauvoir; The Second Sex; biology; anthropocentrism; neuroscience

\section{Authors details:}

Tone Bleie, Professor, Department of Social Sciences, UiT - The Arctic University of Norway, 9037 Tromsø, Office Phone 776 25123, email: tone.bleie@uit.no

Tone Bleie $(\mathrm{PhD})$ is a Professor of Public Politics and Cultural Understanding at UiT- the Arctic University of Norway. Bleie combines an academic carrier with engagements as an international development professional and human rights advocate. Since the mid-1990s, one of her principal research interests has been creating interfaces between the evolutionary sciences and social sciences, feminist theory included. 


\section{Introduction}

In a much-acclaimed essay, What is a woman? Sex, gender and the body in feminist theory, Toril Moi argues that Simone de Beauvoir's view of the body as situation, as outlined in the famous treatise The Second Sex, is a necessary and sufficient ground for feminist theory (1998, pp. 119-121, 1999a, pp. 81-83). Moi's main ambition is to show that Beauvoir's understanding of woman, femininity, and the body as situation constitute a viable alternative to the post-1960 distinction between sex and gender, which she argues has not been a very helpful building block for feminist thought. Moi criticizes post-structuralist and, especially, postmodern feminist thought for illogical and unproductive theorizing and defends a more materialistically oriented feminism that approaches women within their social and historical contexts.

Moi is far from alone in her longstanding and bold critique of the theoretical mainstream in contemporary feminism as elusively abstract, obscure, and contradictory. Yet, her position as a highly influential reader of Beauvoir's scholarship and an original feminist theorist beyond her studies of Beauvoir, created an advantageous starting point for her to reach out to extensive international feminist constituencies, both in the Nordic countries and beyond. The reserved responses to her constructive and timely critique bespeak the graver difficulties facing feminist scholars whose materialist theoretical foundation is profoundly evolutionary. Persistent epistemic barriers, underpinned by group-think, continue to hamper mutually enriching intellectual debate and scientific innovation.

Now, considering Beauvoir's magnum opus, The Second Sex, first published in 1949, the most illustrious and commonly shared insight is probably that biology does not make the category "woman", but rather it is social reality in the form of deep-rooted gendered structures, and interpretations, in historical trajectories. ${ }^{1}$ Partly influenced by this general and imprecise understanding, the first volume of The Second Sex, comprising theoretical and empirical discussions of biology, history, Marxism and psychoanalysis, is basically understood to set out the theoretical framework for explaining patriarchy in Volume 2. This latter volume applies a life-course perspective in its account of women's subordination and alienating experiences. Said differently, the chapters in Volume 1 dealing with biology are not understood as a standalone theoretical work in their own right, but as a link to Volume 2 insofar as they help to explain the formation and content of patriarchal ideology in prehistory and history. When this author, together with a Finnish colleague, Anna Rotkirch, embarked more than a decade ago on a project to engage in a fem-Darwinian reading of The Second Sex, feminist colleagues asked 
us what more did we expect to find than Beauvoir's extremely well-known analysis of scientific myths? We were also told that post-Beauvoir feminist critiques of the philosophy of science had become increasingly more sophisticated. Put plainly, an analysis of The Second Sex undertaken mainly from the vantage point of the first volume, risked becoming a rather trivial endeavour.

The argument was, and remains in this paper, that Volume 1 deals with the unravelling not only of myths, but also of evolutionary and biological facts which, in Beauvoir's own terms, “cannot be denied" (pp. 66-67). Moreover, Beauvoir's treatment of biological data is in several respects exemplary, even judged against today's standards, in the sophisticated engagement of her eclectic existential philosophy with science. This view makes Volume 1 much more than a stepping stone to or an underpinning for Volume 2. It is a rich tapestry in its own right against which to discuss Beauvoir's comprehensive theory of nature, enabling a woman-centred understanding of non-human species and humankind throughout prehistory and history. Beauvoir's grand theorizing should provide for an indeterminate future, unchaining us from our past destiny as slaves of the human species. ${ }^{2}$ I would maintain this characteristic of her intellectual achievement, knowing full well how she liked to disassociate herself in public debates from the perception of philosophers as lone creators and system builders.

This article therefore highlights certain overlooked, but major, insights alongside some intriguing flaws in Beauvoir's work regarding evolution and life-course development - insights and flaws that Moi, for example, five decades later, only touched upon cursorily in her influential re-reading of The Second Sex. ${ }^{3}$ The scope of the analysis in this article does come with a caveat, however. A truly comprehensive enquiry into Beauvoir's relationship with science would have to include her exposure to and intellectual thinking about science since her student days, including her relations with numerous science scholars, such as, for example, Claude Bernard and Jean Piaget.

While the chapters on biology have been subject to interpretations by both postconstructionist and materialist feminist theorists (cf. Moi, 1986, 1994, 1999a; Butler, 1986, 1993; Ward, 1995; Fishwick, 2002; Langer, 2003; Gatens, 2003; Hird, 2004; Jordan-Young, 2010), strikingly few of the materialist readings have fully taken on board Darwinian knowledge about the accumulation of complexity through selection mechanisms and the implications for a theory of the embodied mind and situated choice. I therefore hope to supplement this body of knowledge in at least four areas. The first highlights Beauvoir's 
genuine curiosity about the natural sciences and her firm conviction of the pivotal importance of the knowledge that biology provides about reproduction in both non-humans and humans alike, together with human life courses in particular. Said differently, her intellectual struggle to engender an enriching dialogue in writing and speech between (her version of existentialist) philosophy and science remains exemplary. The second area concerns her shrewd methodological approach to distinguishing science from pseudo-science, and how to expose implicitly consequential and politically value-laden presumptions, both in the production of scientific data and their interpretative uses. She stumbles at times in her critical treatment of biological theories and facts, revealing an attachment to competing philosophical ideas and a blindness to ambiguities in her principal reasoning. But this should not render her uncompromising intellectual struggle for big theorizing any the less instructive today. The third area covers Beauvoir's evolutionary and biology-informed arguments on the irreducible and contingent nature of sexual differentiation, human sexual reproduction, and the parent-infant bond, not to mention her anthropocentric stance. Together, they amount to an original contribution to natural history and a critique of the philosophy of science, matters that Moi (1986a), Fallaize (2001), Simmons (2003), Gatens (2003), Mudde (2015), and Peňa-Guzmán (2016) have partially addressed. Finally, I briefly highlight certain important insights from neuroscience and primatology that might conceptually enrich and empirically ground a nonanthropocentric stance and non-dualistic notion of the mind-brain continuum and a theory of the body as a situation. Space constraints do not permit much elaboration here of the diverse body of works (cf. Lakoff \& Johnson, 1999; Edelman, 1992, 2004, 2006; Frank et. al 2008; Fernando, Szathmáry, and \& Husband, 2012) which approach the question of mind-brain, embodied meaning, and lived experience in ways that do not represent the stereotypical understanding of bio-scientific objects, but rather approach the entangled mind-body nexus in a multi-faceted, processual, and empirically grounded way.

Feminist studies today are characterized by a range of theoretical positions; from the moderate constructionists, with varying materialist convictions ranging from phenomenological to evolutionary positions, to the radical constructionist positions of the postmodernists and poststructuralists. I will discuss Beauvoir's account of the biological sciences from my own stance as a social scientist who is a moderate constructionist. My discussion will draw upon a wide array of instructive readings by Beauvoir scholars from the Nordic countries and beyond. Approaching Beauvoir's materialist notion of the situated body, painstakingly aware of the magisterial range of issues that she deals with in The Second Sex, I will confine this scrutiny to 
a critical analysis of her phenomenological notion of the biological body and the body as a situation. In the final sections, my analysis will gradually shift from a predominant focus on the dialectics between Beauvoir's reasoning with close collaborators and intellectual adversaries, to discussing her remarkable theoretical edifice in light of current research frontiers of relevance to a Darwinian materialist constructionist or a moderate constructionist stance.

Over the last few decades, evolution-informed cognitive and biological sciences have made ground-breaking discoveries concerning the embodied and the evolved mind. The studies that have inspired me are Darwinian, in the sense that they would claim that evolutionary insights are of relevance to many of the inter/disciplinary social, psychological, and economic subjects that have preoccupied me. The reaction from women's, gender and feminist studies towards these developments has until recently been lukewarm or even downright hostile. Indeed, the iconic Beauvoir's own treatment of Darwinism and the biological sciences in The Second Sex has been selectively appropriated within influential strands of feminist thought, in order to justify a delegitimization of biology's claim to objectivity. As some prominent proponents of new materialism have argued, there is a strange neglect of Darwin, compared with other classic male thinkers like Marx and Freud, Nietzsche, Derrida, Lacan and MerleauPonty, all of whom have been subjected to prodigious feminist re-readings and analysis.

"Darwin's work is incredibly rich and open-ended. And feminists have, I think, somewhat foolishly neglected his work because the concept of nature or biology has been so alarming", the philosopher Groez says, in an interview published in the feminist journal NORA $\left(2007\right.$, p. 48). ${ }^{4}$

Since the 1980s, some feminist-leaning natural scientists who were pioneers in their respective fields have also written for the feminist academy (Gannon, 1999; Gowaty, 1996; Hrdy, 1981, 1986, 1997, 1999, 2011; Lancaster, 1991; Liesen, 1995; Sayers, 1982; Smuts, 1995; Zuk, 1993, 2002, 2012; Barad, 2007; Roy, 2016), calling for the incorporation of evolutionary understanding into feminist theorizing. In 1999, feminist psychologists launched a journal devoted to this topic (cf. Campbell, 1999) and in 2006 scholars from the social sciences and life sciences launched the journal BioSocieties. Feminist social scientists and humanists (cf. Bleie, 2003a, 2003b; Segerstråle, 1992, 2006; Rotkirch, 2004, 2007, 2014, 2016) and philosophers (Bennett, 2010; Grosz, 1999, 2005, 2011, 2017; Vandermassen, 2004, 2005, 
2011) have also contributed to a more self-critical dialogue (in Beauvoir's sense) of the living body in the context of the entrenched division between the two scientific cultures.

In spite of the diversity of theoretical strands to which these explicitly Darwinian scholars claim adherence (some are acclaimed theorists and not necessarily self-styled oppositional to influential streams of feminist theory), the overall influence on feminist studies as a whole remains limited. It is still possible to publish academic texts on evolution-related themes that display ignorance of the evolutionary sciences, in stark contrast to Beauvoir's avid theoretical and empirical interest in, for example, biology in her acclaimed post-war treatise. Among Beauvoir scholars, there is considerable difference in what kind and how much material life and "biology" one allows. Some are constructionists or postmodernists who assert that one cannot know the body and its lived experiences outside of cultural discourse and social mediation (cf. Butler, 1997, p. 5; Kruks, 1992, p. 105). Phenomenologists tend to be less hostile, but emphasize a strong and fixed division of work between the humanistic and the natural sciences (cf. Heinämaa, 1999, 2003a, 2003b, 2005, 2006, 2014; Moi, 1986a, 1986b, 1994, 1998, 1999a, 1999b, 2002, 2007; Mudde, 2015). For instance, phenomenologist philosopher Sara Heinämaa summarizes her reassessment of Beauvoir's theory of embodiment in the statement: "Beauvoir's discussion of sexual difference is a methodological framework in which the body is described as a subject of perception, not a bio-scientific object” (2003a, p. 67). Others, including for example, Toril Moi and Anna Mudde, have argued that the body as situation allows for bridges between different disciplines and scientific cultures. Below, in the first three sections I will discuss Beauvoir's treatment of evolutionary theory and empirical evidence, starting with evolved traits in human sexuality and care for offspring, with an eye for both compelling insights and possible missing links, whose ontological basis I will seek to unravel.

\section{Darwin's dangerous idea: sexual selection - the missing link in Beauvoir's thought}

The first part or volume of The Second Sex has the evocative title "Destiny". The volume is a rich presentation and bold critique of three influential scientific approaches to women: 
biological points of departure, the psychoanalytical perspective, and the historical materialist perspective. ${ }^{5}$ The only direct reference to Charles Darwin is in the first chapter, on biology. Beauvoir depicts the lives of females in non-human species in a rather ghastly way, provoking an array of feminist interpretations. ${ }^{6}$ Animal females are viewed as reproductive slaves with very little if any opportunity to influence or modify their environment and social life. It is in this context that the work makes its single reference to Darwin:

But normally she /the female mammal/ does not seek to affirm her individuality; she is not hostile to males or to other females and shows little combative instinct. In spite of Darwin's theory of selection, now much disputed, she accepts without discrimination whatever male happens to be at hand. (Beauvoir 1997, p. 55)

In The Descent of Man and Selection in Relation to Sex (1871), Darwin first proposed the radical idea that females actively choose their male sexual partners. This view was in stark opposition to then-prevailing bourgeois notions of feminine sexuality as inherently passive. Many of Darwin's contemporaries ridiculed his view. Beauvoir agrees with those who criticize Darwin's sexual selection theory and instead claims that males decide when to have sexual intercourse and with whom. Beauvoir thus favours an interpretation of sexual evolution that downplays female agency. Why so? It cannot be best explained with Social Darwinism's bad repute in Beauvoir's intellectual circles (Cronin, 1992). There were opposing voices in the academy, whose findings did not catch the attention of the Parisian intelligentsia. In spite of Beauvoir's interest in evolutionary theories and biological facts, she evidently chose not to read contemporary Darwinists or the original treaties of Darwin. With the intellectual ambition to establish a comprehensive theory of women's subordination and alienation, while building on facts from modern science, her rejection of Darwin's sexual selection remains an enigma, even in light of her deep scepticism towards natural law, embracing all animals, including homo sapiens. Indeed, Darwin's dangerous theory should have been taken as a welcome refutation of a natural law for all species. Beauvoir might in this case have committed a kind of explanatory cherry-picking, a scientific (mal)practice she critiques brilliantly. Using concrete cases, she often demonstrates how theories claim more explanatory ground than they can justify, by disregarding evidence that would falsify their claims.

Despite the above-mentioned single direct and mistaken reference to Darwin, The Second Sex makes insightful comments on certain evolved traits in human sexuality. Beauvoir notes that a man can father 100 children while a woman can at most give birth to 25-30, and then 
only with huge physical effort (1997, p. 48). She also stresses that mammal females bear the main physiological and social burden of raising children. Her arguments show a resemblance to the biological terminology of asymmetrical parental investment; a trait common to most sexually-reproducing species. Usually - but not always - females are the sex investing more in their offspring. The first volume of The Second Sex does not adequately develop the consequences of this initially unequal human reproductive burden during the Palaeolithic period and after the Neolithic revolution (Bleie, 2003b; Hrdy, 1997). Rather, Beauvoir seems to conclude that the sexes' unequal risk-taking in reproduction provides modern women with a good reason for avoiding motherhood altogether. ${ }^{7}$

Sexual differentiation in reproductive behaviour constitutes one of Beauvoir's prominent thematic interests. She shifts from scrutinizing sexual partner choice, to infant-rearing and the rise of the human family in prehistoric and historical times. In accounting for the latter, Beauvoir's main sources are a contemporary intellectual, the French anthropologist Claude Lévi-Strauss, and the classical work of Friedrich Engels and James Frazer on the origins of the patriarchal family. Lévi-Strauss's principal focus on cultural instead of naturalistic explanations matched her radically "situation-oriented" view of psychological diversity. She quotes Engels and Frazer in the chapters on biology and history to illustrate the specific cultural and social configurations underlying women's subordination in prehistoric and modern societies. In this context, Beauvoir approvingly quotes depictions of a seemingly infinitely malleable human nature. For instance, she claims that prehistoric emotional bonds between mother and child and between women and men were shallow, and that males had no notion of paternity (Beauvoir, 1997, pp. 69, 98). In view of current anthropological knowledge, these claims are exaggerated. Human family relations do vary, but not infinitely so. Nowhere is the emotional tie between mother and child culturally radically ignored. Maternal attachment to their offspring evolved before Homo sapiens did and is found among our closest primate relatives. Paternal attachment is (as Beauvoir argues) a more recent evolutionary invention (Hrdy, 1999, 2011; Wade, 2003) integrated into human cooperative breeding systems that depend on having fathers as well as other kin and adults caring for a child (Geary, 2008, p.123; Hrdy, 1999, pp. 235-257).

Such evolutionary ideas were not new when Beauvoir wrote her magnum opus. Sociologist Edward Westermarck's bestselling work, History of Human Marriage, first published in 1891, stressed the universality of the romantic pair-bond between adults and the parent-child bond and remained fairly influential ${ }^{8}$. His influence is discernible in the works of one of his most brilliant students, the Polish anthropologist Bronislaw Malinowski (1930), in 
which he characterizes the mother-child bond as not only a universal feature of human societies, but "the most individual of social forces". His argument entered a heated public debate on how expanding modern childcare facilities would influence the mother-child bond (Montagu, 1956, p. 51). Now, consciously or not, Beauvoir chose to side with those belittling any evolved psychological traits in general, not just in the case of the maternal-infant bond. A crucial question then becomes: did she thus reject the contributions of evolutionary theory to the understanding of human behaviour, including basic emotions? This central question will be addressed successively in the coming sections of this paper.

Forty years after the initial publication of The Second Sex, Moi forcefully criticizes those feminists who would discard any naturalistic understanding of human beings. The problem does not lie in biology, she says, with reference to Beauvoir's original argument, but whether biological knowledge determines what women can and should do. When Moi employs her disciplinary lens, seeking to make sense of Beauvoir's choice of imagery in the opening paragraph of the chapter "biological data," she is struck by Beauvoir's imagery of monstrously large egg cells and unsatisfied spiders. Moi interprets these ghastly evocative terms as representing a deliberate ironic parody of a deterministic sex theory (Moi, 1986; 1998, p. 93). Zerilli (1992) has suggested that this genre of writing might be not so much irony or dismissal, as a provocation and challenge. Moi's argument makes absolute sense from a literary perspective. Yet I wonder whether both Moi and Zerilli are not too fixated on narrative strategy at the expense of the substance and length of these mind-boggling statements? What I find most striking is Beauvoir's wealth of up-to-date knowledge about biology, leading to an astonishingly detailed account of reproduction. Based on the huge effort Beauvoir must have invested to collect and make sense out of a considerable body of biological research and its lengthy elucidation in The Second Sex, I question Moi's argument.

Another pressing question remains unanswered. Why did Beauvoir choose to discuss at such length a number of misogynistic French and British scientists' views of sexual selection as premised on a passive female and an active male, instead of Darwin's radical view of the sexually active female? Moi, for example, refrains from explaining why Beauvoir attributes so much importance to these misogynistic scientists, while ignoring Darwin. ${ }^{9}$ Could it be that Darwin's idea that natural selection acts on the human brain and on the mind and psychology was deliberately rejected as contrary to the transcendent condition that modern women could aspire to? The whole idea of an evolved mind, at the very least, complicated her project immensely. Possible conscious motives and scholarly deliberations aside, the fact that Beauvoir 
refrained from developing Darwin's dangerous idea was a very consequential decision indeed. In order to probe deeper, it is essential to try to deconstruct the tangled concept of biology.

\section{What is biology?}

There is absolutely no doubt that Beauvoir acknowledged the existence of biological facts. She sought, for example, to distinguish factual from fictitious genetic influences in evolutionary time and human life courses, both mediated and unmediated. But how did she actually debate mediated influences? Moreover, did Beauvoir primarily conceptualize genetic and psychological, social and cultural pathways as irreducibly distinct in humans?

The introductory chapter of The Second Sex is devoted to recent discoveries in reproductive biology. Firstly, Beauvoir stresses that the division into two sexes is not the only means of reproduction. The spool worm's asexual reproduction, and the sexual bipotentiality of some varieties of toads, are instances discussed. Having discussed the striking plurality of forms and developmental processes, Beauvoir argues that none of them is superior or morally preferable. For any species, evolution took one of many possible routes, even if the result is eventually stable. She concludes that sex is both contingent and irreducible, an insight in line with the ideas of contemporary biological science. Beauvoir underlines the difference between gamete specification and phenotypes and discusses the contributions of both the sperm and the egg cell to reproduction in species with (mainly) two sexes, such as humans. She pays considerable attention to the difference in size of the gametes, stressing that both cells are of basically identical importance for future offspring. Both lose their individuality in the act of conception as they merge with each other (1997, p. 45). She criticizes dubious analogies which define sperm as the more active and important element compared with the behaviour of the egg cell $\left(1997\right.$, p. 46). ${ }^{10}$

Beauvoir elegantly drew on contemporary science to refute the outdated claim that a gamete mirrors individual behaviour. "In the unfertilised egg cell," she wrote, "not even the concept of femaleness is yet established. As Hegel justly remarks the sexual relation cannot be referred back to the relation of the gametes" (Beauvoir, 1997, p. 46). This sentence is persuasive and crucial to Beauvoir's justified attack on so-called psycho-physiological parallelism: that psychological womanhood stems directly from the nature of the egg cell. Her critique certainly remains true. Nevertheless, in contemporary biology a concept of female is actually included in the egg cell, since the size of the gamete is used as the only criterion for defining sex: the 
individual with the bigger gametes is termed female. Such a metric definition is a very far cry from any psychological or even physiological parallelism of gamete and mind. But, in fact, no secondary traits can be assumed a priori for either sex.

Unlike the misogynistic works that build on natural law perceptions of sexual differentiation or ontological perceptions of sexual difference as hierarchy and a precondition for human society, the contemporary biological definition does not assume any essentialist and unchanging femininity (Kokko \& Jennions, 2014). If a species evolves such that sperm cells grow larger than the egg cells, the sex that currently produces sperm would be defined as female. ${ }^{11}$ Had Beauvoir and her scholarly readers more fully relied on biology's definition of sex, they could have further strengthened her two-sided argument; secondary characteristics are not automatically linked to gamete characteristics, and gamete specification (resulting in different reproductive functions) does not result in one dominating the other.

Beauvoir undertakes an elaborate description and analysis of sexual differentiation (including dimorphism of forms) in primitive life forms and homo sapiens. Intrigued, she observes that "life gets more individualised" the more complicated the forms become. Rudimentary life forms eat and reproduce. Some species are free from rearing offspring for long periods. Often, the male is freer from reproductive tasks than the female, and this creates tensions between the sexes. ${ }^{12}$ Beauvoir (1997, p. 57) reasons that the human female, "the most individualised of females - seems to be the most fragile, most subject to this pain and danger: she who most dramatically fulfils the call of destiny and most profoundly differs from her male". Her contention that sex differences, including dimorphism, in humans would be larger than in other species, lacks evidence. Her empirical knowledge and curiosity have their limits. The celebrated Beauvoir did not venture from Café de Flore to her own city zoo, Ménagerie, Parc Zoologique de Paris, to observe at first hand the sexual dimorphism in non-human primates.

It is instructive to scrutinize the selection of topics that Beauvoir chose to prioritize in these two chapters. Her theoretical interest is plainly in physiology as an intersection (and battlefield) between society and biology. She examines brain (intelligence) research on both non-human primates and humans and how scoring results not only speak to objective differences in brain size and composition, but are often riddled with sexist, racist and anthropocentric pre-judgements. Such an important and bold critique aside, Beauvoir's perception of the evolutionary differences between humans and nonhumans is fundamentally 
anthropocentric and somewhat pre-Darwinian. Her postulate of a fundamental difference is critical to her existential philosophical position, anchored in transcendence. Towards the end of this section, I shall return to what motivated Beauvoir's consuming interest in contemporary and established evolutionary insights; namely, her grandiose philosophical project, which was also a philosophy of life and lifeforms. Beauvoir's theorizing about reproductive physiology, basically sexed bodies and physical sexual reproduction, has had a considerable intellectual and political impact for more than half a century. Depicting women with the famous expression "the enslavement of the female of the human species", Beauvoir (pp.59-69) uses the terms "trial", "crisis", and "servitude" to describe the physiological processes of menarche, childbirth, and breastfeeding. Only menopause saves women from the excessive reproductive burden. After Beauvoir's demise, a tide of Darwinian studies by anthropologists and primatologists on sexual selection, reproductive choice and cooperative breeding have partly contradicted Beauvoir's anthropocentrism, but partly confirmed her understanding of how female nature basically limits female choice (Hrdy, 1999, 2009; Jolly, 1999). Beauvoir is refreshingly cynical when she outlines the challenges of women's dependency on children and lovers. Her candid discussion of the ties between offspring and mothers partly echoes another key topic of contemporary evolutionary theory: parent-offspring conflict. This concept denotes the tendency of offspring to want more parental care, resources, and attention than the parent is willing to provide. ${ }^{13}$

As noted, Beauvoir rejects psychophysiological parallelism, including hormonal influences on the psyche. She is hard-hitting and principled in her rejection of claims that reproductive physiology determines female psychology and behaviour. In spite of this categorical stance, she does not preclude certain hormonal influences on sexuality (1997, p. 66). When discussing the influence of menopause on female sexuality, Beauvoir readily recognizes the psychological implications of hormonal changes: "Woman is now delivered from the servitude imposed by her female nature, but ... her vitality is unimpaired. ...: she is herself, she and her body are one" (Beauvoir, 1997, p. 63). Is this because menopausal hormonal changes are less potentially enslaving than those affecting the reproductive woman? Her view of when "biology" as reproductive physiology matters is not only eclectic, but occasionally illogical and confusing.

At this stage, it might be useful to take a step back and remind ourselves of the grandeur of Beauvoir's encompassing philosophical project. It motivated and directed her strategic interest in biology, including her engagement with the analytical and empirical issues I have outlined so far. It also explains the final area listed above, embodiment and situational choice. 
This French philosopher aimed to create a sweeping account of the human condition informed by natural history. Indeed, she intended to account for the poorly understood entanglements of evolutionary, historical, and social forces (both facts and myths) that shaped women's position and embodiment through different prehistoric and historic times up to her own time, and to formulate the preconditions of a new freedom, unprecedented in the history of womankind. This is grand theorizing, informed by her dialogical scientific practice.

I have attempted so far to underscore Beauvoir's intellectual brilliance in understanding and appropriating difficult biological facts, building specific insights from these facts, rejecting spurious claims, and transforming valid data into a series of distinct arguments, on which she built her ambitious theoretical project. They constitute, in brief, a rejection of ontological proof of a natural law of sexual differentiation; an argument in favour of differences between gamete and phenotypic specifications and of plasticity (based on empirical studies in evolutionary genetics); and an argument against psycho-physiological parallelism, but in favour of evolutionary hierarchy between humans and other animals (a deeply anthropocentric position). And, finally, there is her natural history theory, which classifies animals hierarchically according to different principles (variable individuality, sexual monopolization, and sex functionalism through continuation and rupture), rather than Darwin's theory of common descent.

In her grand theory, with its metaphysical underpinnings, Beauvoir in certain respects broke with Darwin's logic of a common descent and sexual selection based on female choice. She also, inventively, tweaked particular evolutionary topics to fit in with her own alternative, ladder-like natural history scheme. As shown above, at times she fell prey to selective interpretation of facts and inconsequential reasoning. For example, she could accept hormonal influences on the ageing female body. If the psychological effects of the menopause were partly hormonal, how could she maintain that the desire for babies and maternal depression are explainable solely on the basis of social and cultural factors? There is something deeply unsatisfactory here about the concept of biology. Does evolution "stop at the neck", to use psychologist Ann Campbell's (2002, p. 13) apt expression? Could the missing Darwinian link, discussed above, as a legacy that theorizes both environmental and genetic effects, and interactions between the two, represent a major cause? Although Beauvoir's judicious and critical thinking on the compass of biology was not wholly consistent, most of her own and her intellectual predecessors' views on woman's social or second nature (societal norms and practices) have become not only the most important, but completely separated from the human's 
first nature (biology). This ontological precept is also mirrored in an epistemological view of how to study the body as situation and from which (inter)disciplinary perspectives.

\section{How to study the body as situation and choice}

Following the discussion of biological insights concerning asexual and sexual reproduction in the first volume of The Second Sex, Beauvoir announces her key concepts of embodiment and her main theoretical inspirations. "In the perspective I am adopting - that of Heidegger, Sartre and Merleau-Ponty - if the body is not a thing, it is a situation: it is our grasp upon the world and the outline of our projects" (1997, p. 66). Several theorists have made detailed analyses of Beauvoir's mainstay in phenomenology as a foundational science and her eclectic use not only of the scholars she cites above, but of others too, such as Edmund Husserl, who was a major influence on Merleau-Ponty. It is beyond the scope of this paper to recapitulate this debate even briefly. Instead, I examine two influential readers' arguments before providing a brief evolutionary-informed exploration of the notions of the living body and lived experience, based on my finding that the first volume offers a more intricate and multi-layered integration of philosophy and science than is usually recognised.

In What is a Woman?, Moi devotes a chapter to the concept of the body as situation, beginning with an attempt to clarify what Beauvoir means by this probing yet exceedingly multi-vocal and vague statement. Arguing against a radical constructionist interpretation, she notes that the statement does not imply that the "physical capacities of either sex gain meaning only when placed in a cultural and historical context" (Moi, 1999a, p. 59). But, at the same time, Moi convincingly stresses the importance of Beauvoir's bold effort to counteract biological determinism. She underlines the significance of the term "lived experience", as the way in which an individual imbues her situation with meaning, and characterizes accumulated experience (sedimented) as situatedness. I find this argumentative turn intriguing, but problematic. Moi insists on the one hand on the centrality of memory, but as social memory, therefore implicitly rendering cognitive science irrelevant. On the other hand, she characterizes changing situations as interacting in a dialectical process with lived experience. What I miss is an informed interdisciplinary explanation of an externalized-internalized memory continuum and how embodied memory actually intertwines with the category of experience. Moi seeks to illuminate Beauvoir and Sartre's shared notion of the situated, individual project as grounded in a sociological understanding of the durable structural dimensions (class, ethnicity, nationality, etc.) which form the social body. 
Moi elaborates upon Beauvoir's use of Merleau-Ponty's conceptualization of the body as fundamentally ambiguous; a site for both the laws of nature and the production of meaning (1995, pp. 102-107). ${ }^{14}$ She argues that Merleau-Ponty's understanding of the ambiguity of embodiment is premised on his notion of the human, not as a natural species, but as a historical idea (1998, pp. 95, 103). This formulation is potentially confusing and illogical. ${ }^{15}$ Leaving aside this distracting expression, I register their respective texts as containing subtle similarities, pivoting around both stated and implicit common understandings of human nature.

Beauvoir appropriates Merleau-Ponty's notion of the expressive body in several of her works in The Second Sex. The terms "artificial" versus "natural" are employed to argue that every word and action is not "pure" biological existence, but redirected/or redefined through a sort of ambiguous genius that defines a human. Merleau-Ponty's argument is used in order to stress the radical difference between human evolution and that of non-humans in both evolutionary time and ontogeny. Beauvoir develops these assertions in a concrete sociological direction through her elaboration of values and customs as non-reducible to biology. She does not discuss the social life of animals, nor the evolutionary selection mechanisms through which the human capacity for symbolic processing, language and morality evolved. Once protohumans with a brute nature had evolved, the dawn of culture (as second nature) and civilizational processes took over, unleashing human life forms. The phenomenological tradition of engaging with the natural sciences and empirical science is complex. Beauvoir was an original thinker on sexual difference in terms of a phenomenology of the living body. I would argue that her notion of the human body as a subjective grasp on the world is not solely based on theoretical inspirations, but also her prodigious analysis of new empirical evidence of both the fluidity and the fixity of life trajectories. But, importantly, she remained torn between her phenomenological understandings of the living body and the objectified biological body of the natural sciences, which she was taught as a student (Simons, 2004, pp. 27-29).

This epistemology of biology - equated with an instrumentalist, objectifying and physicalist and way of doing science - has been too uncritically embraced since Beauvoir died. We have ended up with a generation of feminist scholarship emphasizing the unique mental qualities of humans and the body as a situation and an object grounded in two different and opposed scientific traditions. I shall briefly highlight a few promising naturalist research fields that can help end this impasse, if incorporated into feminist theory building. These studies of embodied, situated minds demonstrate that the epistemological and ontological distinction between the naturalist and humanistic/feminist studies, between the body as a thing and a 
situation and between the mind and the brain, is unwarranted, and prevents fruitful critique, interaction and reorientation.

Neuroscience is one promising contemporary approach for feminist theorizing of the embodied mind-brain. One of its evolving sub-fields, termed Neural Darwinism and Evolutionary Neuro Dynamics by its leading scholars, uses Darwinist principles to develop a new dynamic understanding of a system of somatic selection, operative in life courses and over long evolutionary time spans. ${ }^{16}$ I speak here of elements of a theory of the intricate multi-scaled interactions between brain, body and the natural, social and cultural environment. Such recent emerging insights into the matter and hidden workings of the brain, include our sensory motor system, which contributes to our ability to conceptualize and reason, as well as to conceptual systems, inference, meaning and language. Higher brain functions include conceptual and perceptual categorization, memory and learning, as inseparable aspects of any mental and bodily performance (cf. Lakoff \& Johnson, 1999; Edelman, 1992, 2004, 2006).

Sedimented memories, a term that Moi (cf. 1999, p. 63) uses, alludes to how fragments of memory in the stream of consciousness sink down to the bottom for storage, from which they can be retrieved. The question is: does her vague, poetic and intuitive prose adequately convey state-of the-art scientific knowledge of how human neural-grounded replicative memory actually operates? Sedimented is quite a misleading metaphor, in view of the dynamic nature of the biological and cognitive constitution of memory, as understood by the already mentioned neuroscientist and winner of the Nobel Prize in medicine, Gerald Edelman, and his colleagues (cf. Edelman, 1992, 2004, 2006; Fernando, Szathmáry , \& Husband, 2012). Memory structures the flow of social experiences and bodily movements and through this process reorganizes itself neurally (Edelman (1992, p. 102). In any dynamic cultural and environmental context, recall is not due to fixed accumulated sediments in the brain, but consists of vast, immensely intricate distributed neural networks whose firings respond to changes in the dynamics of neural structures (involved in earlier categorizations) in an incredibly rapid interplay with bodily movements and social action.

Feminist theorists have predominantly been concerned with memory as a socially created phenomenon, embodied in social and ritual practices. Social memory, like all memory, has evolved through natural selection and is neural-based, operating on the basis of biological re-categorization. Combining memory with concept formation, scientists are currently developing startling insights into consciousness itself as consisting of intertwined social- 
biological processes. To Beauvoir, consciousness was the basis for experience, a non-bodily feature of an individual's meaning making, an intentional force for the free discovery of meaning and being in the world. Beauvoir recognized an ambiguity in consciousness as a quest - doomed in part to fail for women. Existentialism would characterize consciousness as spontaneously reaching out into the physical world, a world devoid of intentionality. Humans would, all the same, strive for a synthesis between being and void, and would become ethical beings in realizing this paradox. Applying recent neurobiological understanding, consciousness is of two kinds. Primary consciousness is a state of awareness in the world right now. It lacks a notion of a personal self, and cannot model a past or a future, based as it is on its snapshot sense of the present (Edelman, 1992, p. 120). Humans share this kind of primary consciousness with chimpanzees, and probably with a range of other mammals and birds. As studies find mounting evidence of non-human primates executing purpose-driven activity, mobilizing longer-term memory, consciously altering foraging strategies, using purpose-driven self-made rudimentary tools, and showing precursory self-awareness, our understanding of the unconscious and conscious mind might have to be reformulated (Boly et al., 2013). Such ground-breaking insights dismantle Beauvoir's anthropocentric hierarchy between humans and other primates, based on her assumption (firmly anchored in Western philosophy) that only humans can build a remembered past, learn from experience and be self-aware.

It is unrealistic here to outline in even a rudimentary manner the possible theoretical implications for gender and feminist studies of the ground-breaking scientific findings of Neural Darwinism. Nevertheless, let me attempt to briefly characterize some emerging models, with caveats. The mind arises as a process and as a product of physical interactions across different levels of organization, from the molecular level to the socially constructed and moulded. Arguably, such models of the mind provide promising insights into the mysterious phenomenon of consciousness, our embodied social selves, and the irreducible subjective feeling of being conscious. This feeling is scientifically affirmed as a profoundly individual emergent property of social interaction, notably selected-for during evolution and wired into our brains. This subjective feeling is what phenomenologists from Husserl to Beauvoir and Moi claim is our proper and only subject area. In consciousness studies, there is no qualia-free observer. Therefore, theory is not built around an objective observer claiming a "God-eye's view of consciousness" (Edelman, 1992, p. 115). The very properties of consciousness and the heterogeneity of human capacities are sought to be explained by understanding both the biological functions and processes that underpin consciousness and the ways in which they 
mesh with the recursive symbolic properties of language and gestures as embodied action. We are speaking of an empirically grounded understanding of entanglements, not a mixing of discrete social and biological elements. The dynamic activity of networks of neurons which create conscious experience are based on three selectional principles: development selection during the embryonic and foetal stages; experiential selection (leading to synaptic modifications) during the lifecycle in interaction with social, cultural and physical environments; and re-entry during development. The latter governs spatial-temporal coordination between neural networks, based on a flurry of exchanges between different networks of the brain, leading for example, to the integration of colours and movement of visual objects.

The Darwinian thinking behind this conceptualization of brain creativity, plasticity, formation and function principally concerns variations within and between individual embodied brains which, based on phenotypic limits, engage mentally, socially and physically. Mental life emerges through a staggeringly advanced interplay of outer worlds and inner subjective realities. Recent empirical investigations reveal the brain's creativity, such as its creation of perceptual illusions, its use of calculated guesses by "filling in" ambiguous sounds from voices (e.g. the quintina or fifth voice) or instruments, making inferences based on past remembered experiences of vibrating sound waves hitting the eardrums (cf. Pressnitzer, Suid \& Shamma 2011).

This brief characterization of recent discoveries about how coherent perceptions of colours and music are formed - phenomena that are neither basically gendered nor sex differentiated - is deliberate and indicative of my refusal to limit this debate to genderdifferentiated functions and processes, based on an essentially sex-differentiated brain epistemology, including the application of the binary pair of female and male brains. Interestingly enough, Beauvoir's biologically grounded insights into both sexual and nonsexual differentiation and plasticity were remarkably early, and a forerunner of such an epistemological position, which can capitalize on scientific discoveries made during recent decades of the embodied mind that were unavailable to her. Brain plasticity (theoretically far from new, but its empirical study has advanced remarkably since the 1970s), is currently comprehended as a process of change in the strength of billons of synapses, yielding responses within a fraction of a second to social events, as well as emotional, visual and aural stimuli. 
In concluding this section, I want to situate my arguments in the context of recent debates in Critical Neuroscience, the recent interdisciplinary sub-field of feminist materialist studies that I mentioned earlier in this article. This evolving sub-field is composed of neuroscientists with diverse specializations (psychology, cognitive science, linguistics, endocrinology, physiology, anthropology etc.), and aims to invigorate research programmes that advance feminist and queer perspectives. In this field, different concepts of gendered/sex/ual differences, sameness, variability and plasticity collide, encouraging engaged scientific and political debates about concepts and possible mediatory theoretical and analytical concepts that are mutually productive (and politically acceptable) in advancing new inquiries. In a recent review-cum-essay in Signs on new directions in neuroscience-influenced feminist theory, neuro-endocrinologist Debolenna Roy (2016) takes as her starting point a three-pronged definition of difference: a) sex differences observable in what she terms male, female and intersex brains; b) sexual differentiation as a descriptive term for the effects of $\mathrm{X}$ and $\mathrm{Y}$ chromosomes and genes, including the feminization/masculinization of organs and behaviour; and c) sexual difference as an ontological concept in poststructuralist theory (Roy, p. 535). Recapitulating intellectual history research on sex differences, based on these definitions, Roy uses considerable space to discuss the controversies around findings linking hormonal and morphological sex differences in the brain with sex-differentiated behaviour. Notably, Roy traces this field of inquiry back to the mid-1980s and the pioneering works of Ruth Bleier, Anne Fausto-Sterling and Lesley Rogers. In view of my analysis, the intellectual pedigree of this line of research could profitably have been extended back to the first volume of The Second Sex. Roy observes that the content of current feminist criticism of the essentialist and binary claims of neurologists (including feminist scholars) is not really so very different today than it was 2530 years ago. I think her assessment is largely correct, reflecting a continuing rift between different epistemic cultures, affecting our ability to rethink differences, sameness and variability. In my own reading, a persistent feminist criticism levelled at social scientists like myself, who incorporate a brain-based epistemology, and scholars like Roy from the life sciences, can be encapsulated by the expression "damned if you do and damned if you don't". If we maintain that sex differences are negligible or not especially salient, we are taken to task for tactically avoiding sensitive topics that would predictably mobilize feminist critique. And if we examine findings that provide evidence of specific sex/gender differences in the processes of the brain, we are accused in sweeping terms of "essentializing" them. Roy prefers a theoretical stance (p. 543) based on her third definition, a neo-materialist notion of sexual difference as a fundamentally dualistic ontology, which, she argues, will pave the way for 
thinking about an infinite multiplicity of sexed brains. I remain unconvinced about this highly abstract ontological stance regarding brain differences for two reasons. Firstly, I doubt whether it will be very helpful to Roy's own exciting empirical investigations into biological variation in neuro-plasticity. Secondly, I find that it does not sufficiently take into account neural and psychological evidence of quite staggering non-sex/gender variability during life courses. Rather, I would argue, we should at this stage of main-brain inquiry refrain from pursuing a sex/ual difference-based fundamental ontology and instead pay closer attention to the mounting evidence of an expanding range of complex pathways for variability in human brains.

Conclusion: Towards a naturalistic, feminist theory

The growing number of feminist scholars who, from the 1980s onwards, have scrutinized Beauvoir's philosophical and socio-historical treatises, essays, novels, memoires and letters, have put much effort into deciphering her philosophical and historical conceptions, her literary qualities, and her own life, both tragic and heroic, as an intellectual, childless/free woman. Some have sought to establish or rehabilitate her as the iconic feminist Ur-mother, others have avoided the moral high ground to paint nuanced analyses and portraits. They have gone to great lengths to demonstrate The Second Sex's relevance to contemporary streams of feminist theory, mostly influenced by continental theories such as phenomenology and post-structuralism. Less has been done to scrutinize Beauvoir's naturalistic legacy as articulated in the first volume - in light of Darwinian naturalist approaches to mind, body, agency and freedom. This paper seeks to minimize this gap by providing a more evidence-based perusal of this text's multifaceted theoretical edifice, combining natural history, philosophy, history and anthropology, and thereby helps to reframe and enrich our understanding of The Second Sex's intellectual legacy.

I have highlighted Beauvoir's philosophical meta-framework. This was informed by her dialogical scientific practice and her intellectual brilliance in understanding and appropriating biological subjects and facts, in drawing specific insights from them, rejecting spurious claims and methodologies, and transforming valid data into a series of distinct arguments also informed by natural history. These formed her ambitious theoretical project, into which she incorporated key evolutionary insights, but occasionally tweaked or rejected them to accommodate developments in her own ontological scheme, including her separation of mind and brain and a 
curiously pre-Darwinian concept of a ladder-like hierarchy of life forms, legitimizing an unbridgeable gap between humans and the rest of the animal world.

In developing this grand edifice, she chose not to include Darwin's controversial idea of sexual selection, which conceptualizes women as sexually and socially active individuals with huge intra-sexual variation. I have argued that the reason for this poorly appreciated but, arguably, highly consequential omission was largely philosophical. From an evolutionary feminist vantage point, this omission affected recent decades' Beauvoir-inspired feminist theory, has been reluctant to integrate this important finding into its theorizing of women's agency as a cross-disciplinary, naturalistic feminist endeavour. The omission has contributed to an ahistorical, misogynistic, essentialist and deterministic view of femininity/masculinity and women and men.

Beauvoir's fascinating narratives on evolution and reproduction have been interpreted by some readers as an elegant and effective narrative strategy, exposing androcentricity in science. Others find a free-ranging fascination and curiosity about sexual selection. Based on my naturalistic social science reading of the first volume, I maintain that the extraordinary scope and depth of her theoretical and empirical investigations should warrant a renewed attention to her notions of scientific facts and myths. Her accounts of biological determinism and essentialism as ideological strategies that reduce all women to a static, idealistic notion of Woman that derives its normative force from supposed biological facts, remain an enduring legacy. However, these sweeping insights have diverted readers from her own naturalist orientation and have instead lent legitimacy to a radically constructionist and anti-naturalist intellectual movement, which accept Darwinism as a grand theory of evolution, in a general, but despairingly uncommitted manner.

I have argued for a new appreciation of Beauvoir's perspective on the situated body, as implying a commitment to realism, compatible with modified (naturalist informed) constructionist assumptions. There is a world out there, and we are embedded in it and subject to the laws of physics and chemistry and our own subjective consciousness. Contrary to Beauvoir's distinction between the physiological body and mind, the body as an object and a free-floating sketch, we now have to ponder the fact that our minds and brains are embodied and evolved. This qualified realist claim refutes both naïve empiricist Western philosophy and contemporary postmodern philosophy. We have to discard the awkward culture-determinist idea that the evolution of humans as a species ended in prehistory, and freed us from nature's 
brute forces as immaterial culture took over. Neither should we fall into the trap of reductionist naturalism, built around naïve metaphors of vague similarities between humans and animals in an unspecified sense.

I have drawn on the startling insights into a theory of mind and brain matter contributed by Evolutionary Neural Dynamics as a frontier science, which may help to repudiate thinking about complexity as basically social and cultural, and biology as inert, and stimulate a new sophisticated understanding of mind-brain entanglements. These recent and important insights might conceptually enrich and empirically ground a non-dualistic notion of the mind-brain continuum and a theory of choice and practice. These works approach the question of mindbrain, embodied meaning and lived experience in ways that do not represent the dreaded stereotypical understanding of bio-scientific objects, but rather approach the mind-body nexus in a multi-faceted, processual and empirically grounded way.

This theory of mind should be embedded in a biologically informed epistemology, which understands the mind (embedded in the brain) as a selective system in a Darwinian sense. The world is neither carved out by fixed classical categories, logic or computation, nor variably constituted through a free-floating play of signifiers as asserted by postmodernists. Embodied truths cannot be naïve claims about absolute truths. Neither are embodied truths entirely subjective; humans everywhere share a repertoire of basic emotions and spatial-relations concepts, as a result of our evolved bodily and mental constitution. This position does not refute the existence of a staggering cultural and institutional variety of political and social claims about the alleged nature of sexed and non-sexed, disembodied and embodied facts. In the coming years, I hope to see new ground-breaking claims related to life-course development and gender politics, and its scientific underpinnings, informed by insights into gender-sex characteristics and processes at distinct, defined levels of embodiment: the neural, the cognitive unconscious and the phenomenological. This might renew empirically anchored feminist theorizing of the human and the body as a situation, an intellectual project launched by The Second Sex. 


\section{References}

Beauvoir, de S. (1949). Le deuxième sexe [The second sex]. Paris: Gallimard.

Beauvoir, de S. (1997). The second sex. Ed. and trans. H. M. Parshley (Original edition, 1952); New York, NY: Vintage Books.

Beauvoir, de S. (2003). Det andra könet. [The second sex]. Transl. A. Moberg-Boije \& A. Inczédy-Gombos, with E. Gothlin. Stockholm: Norstedts.

Beauvoir, de S. (2010). The second sex. Trans. C. Borde \& S. Malovany-Chevallier. New York, NY: Knopf. Beauvoir, de S. (2004). Analysis of Claude Bernard's introduction to the study of experimental medicine. Transl. by M. Timmermann. In M. A. Simons (Ed.) Simone de Beauvoir: Philosophical writings (pp. 23-30). Chicago: University of Illinois.

Barad, K. (2007). Meeting the universe halfway: Quantum physics and the entanglement of matter and meaning. Durham, NC: Duke University Press.

Bennett, J. (2010). A vitalist stopover on the way to a new materialism. In D. Coole (Ed.) New materialisms: Ontology, agency, and politics (pp. 47-69), Durham, NC: Duke University Press.

Bleie, T. (2003a). Evas Kamp for Kunnskapens Eple: Betraktninger rundt Feminisisk Forskning [Eve's struggle for the Apple of Knowledge: A view on feminist research]. Kvinneforskning, 27 (1), 32-45.

Bleie, T. (2003b). Evolution, brains and the predicament of sex in human cognition. Sexualities, Evolution and Gender, 5 (3), 149-189.

Boly, M. et al. (2013). Consciousness in humans and non-human animals: Recent advances and future directions. Frontiers in Psychology, 4, 1-20.

Butler, J. (1986). Sex and gender in Simone de Beauvoir's Second sex. Yale French Studies, 72, 35-49.

Butler, J. (1993). Bodies that matter: On the discursive limits of sex. New York, NY: Routledge.

Butler, J. (1997). Excitable speech: A politics of the performative. New York, NY: Routledge.

Campbell, A. (1999). Gender, evolution and psychology: Nine feminist concerns addressed. Psychology, Evolution \& Gender, 1 (1), 57-79.

Campbell, A. (2002). A mind of her own: The evolutionary psychology of women. Oxford: Oxford University Press.

Card, C. (Ed.) (2003). The Cambridge companion to Simone de Beauvoir. Cambridge: Cambridge University Press.

Cronin, H. (1992). The ant and the peacock: Altruism and sexual selection from Darwin to today. Cambridge: Cambridge University Press.

Darwin, C. (1871, Original Edition). The descent of man and selection in relation to sex. Reprint (1981). Princeton, NJ: Princeton University Press.

Edelman, G. (1992). Bright air, brilliant fire. London: Basic Books.

Fallaize, E. (2001). A Saraband imagery: The uses of biological science in Le Deuxième Sexe. In W. O’Brien \& L. Embre (Eds.) The existential phenomenology of Simone de Beauvoir (pp. 67-84). Dordrecht Springer.

Fernando, C., Szathmáry, E., \& Husbands, P. (2012). Selectionist and evolutionary approaches to brain function: A critical appraisal. Frontiers in Computational Neuroscience, 6 (24), 1-20. doi: 10.3389/fncom.2012.00024

Fisher, R. (1930). The genetical theory of natural selection. Oxford: Clarendon Press. 
Fishwick, S. (2002). The body in the work of Simone de Beauvoir. Berlin: Peter Lang Verlag.

Frank M.R et. al (Eds.) (2008). Body, Language and Mind: Sociocultural Situatedness. Berlin/NY: Mauton de Gruyter.

Galster, I. (Ed.) (2004). Simone de Beauvoir: "Le Deuxième Sexe”, le livre fondateur du féminisme moderne en situation.["The Second Sex"- The Life of the Founder of Modern Situational Feminism]. Paris: Champion.

Gannon, L. (1999). A common ground for feminism and evolution. Psychology, Evolution \& Gender, 1 (1), 4556.

Gatens, M. (2003). Beauvoir and biology: A second look. In C. Card (Ed.) The Cambridge companion to Simone de Beauvoir (pp. 266-285). Cambridge: Cambridge University Press.

Geary, D. C. (1998). Male, female: The evolution of human sex differences. Washington, DC: American Psychological Association.

Gowaty, P. A. (Ed.) (1996). Feminism and evolutionary biology: Boundaries, intersections and frontiers. New York/London: International Thomson.

Grosz, E. (1995). Space, time and perversion: Essays on the politics of bodies. New York/Sydney: Routledge and Allen Unwin.

Grosz, E. (1999). Darwin and feminism: Preliminary investigations for a possible alliance. Australian Feminist Studies, 14 (29), 31-45.

Grosz, E. (2005). Time travels: Feminism, nature, power. Durham, NC: Duke University Press.

Grosz, E. (2011). Being undone: Darwinian reflections on life, politics and art. Durham, NC: Duke University Press.

Groez, E. (2017). The incorporeal ontology, ethics, and the limits of materialism. New York, NY: Columbia University Press.

Heinämaa, S. (1999). Simone de Beauvoir's phenomenology of sexual difference. Hypatia, 14 (4), 114-132.

Heinämaa, S. (2003a). The body as an instrument and as expression. In C. Card (Ed.) The Cambridge companion to Simone de Beauvoir (pp. 66-86). Cambridge: Cambridge University Press.

Heinämaa S. (2003b). Toward a phenomenology of sexual difference: Husserl, Merleau-Ponty, Beauvoir. Oxford: Rowman \& Littlefield Publishers.

Heinämaa S. (2005). Through desire and live: Simone de Beauvoir and the possibilities for sexual desire. In E. Mortensen (Ed.) Sex, breath and force: Sexual difference revisited (pp. 145-165). Lanham MD: Lexington Books. Heinämaa S. (2006). Philosophy of Simone de Beauvoir: Critical essays. Bloomington: Indiana University Press. Heinämaa S. (2014). The animal and the infant: From embodiment and empathy to generativity. In S. Heinämaa, M. Hartimo, \& T. Miettinen (Eds.) Phenomenology and the transcendental (pp. 129-146). New York, NY \& London: Routledge.

Hird, M. J. (2004). Sex, gender and science. London: Palgrave.

Hrdy, S. B. (1981). The woman that never evolved. Revised Edition 1999. Cambridge: Harvard University Press. Hrdy, S. B. (1986). Empathy, polyandry, and the myth of the coy female. In R. Bleier (Ed.) Feminist approaches to science (pp. 119-146). New York, NY: Pergamon Press.

Hrdy, S. B. (1997). Raising Darwin's consciousness: Female sexuality and the prehominid origins of patriarchy. Human Nature, 8, 1-49. 
Hrdy, S. B. (1999). Mother nature: Natural selection and the female of the species. New York, NY: Random House.

Hrdy, S. B. (2011). Mothers and others: The evolutionary origins of mutual understanding. Cambridge, MA: Harvard University Press.

Hrdy, S. B., \& Whitten, P. (1987). The patterning of sexual activity among primates. In B. B. Smuts et al. (Eds.), Primate societies (pp. 370-384). Chicago: University of Chicago Press.

Kokko, H. \& Jennions, M. D. (2014). The relationship between sexual selection and sexual conflict. Cold Spring Harbor Perspectives in Biology, 4 (6), 1-13. doi: 10.1101/cshperspect.a017517

Jolly, A. (1999). Lucy's legacy: Sex and intelligence in human evolution. Cambridge, MA: Harvard University Press.

Jordan-Young, R. (2010). Brain storm: The flaws in the science of sex differences. Cambridge, MA: Harvard University Press.

Kontturi K-K., \& Tiainen, M. (2007). Feminism, art, Deleuze, and Darwin: An interview with Elizabeth Grosz. NORA: Nordic Journal of Feminist and Gender Research, 15 (4), 246-256.

Kruks, S. (1990). Situation and human existence: Freedom, subjectivity and society. New York, NY: Routledge. Kruks, S. (1992). Gender and subjectivity: Simone de Beauvoir and contemporary feminism. Signs 18 (1), 89 110.

Lakoff G., \& Johnson, M. (1999). Philosophy in the flesh: The embodied mind and its challenge to western thought. New York, NY: Basic Books.

Lancaster, J. B. (1991). A feminist and evolutionary biologist looks at women. Yearbook of Physical Anthropology, 104 (34), 1-11.

Levi-Strauss. C. (1966). The savage mind. Chicago, IL: University of Chicago Press.

Liesen, L. (1995). Feminism and the politics of reproductive strategies. Politics and the Life Sciences, 14, 145162.

Lundgren-Gothlin, E. (1996). Sex and existence: Simone de Beauvoir's Second sex [Køn och Existens: Studier i Simone de Beauvoirs Le Deuxième Sexe]. Transl. Linda Schenck. Hannover: Wesleyan.

MacKenzie, C. (1998). A certain lack of symmetry: Beauvoir on autonomous agency and women's embodiment. In R. Evans (Ed.) Simone de Beauvoir's The second sex: New interdisciplinary essays, (pp. 122-158). Manchester: Manchester University Press.

Moi, T. (1986a). Existentialism and feminism: The rhetoric of biology in The second sex. Oxford Literary Review, $8(1-2), 88-89$.

Moi, T. (1986b). Simone de Beauvoir: En intellektuell Kvinne blir til [Simone de Beauvoir: The making of an intellectual woman]. Oslo: Gyldendal Norsk Forlag.

Moi, T. (1994). Simone de Beauvoir: The making of an intellectual woman. Oxford: Blackwell.

Moi, T. (1998). Hva er en Kvinne? Kjфnn og Kropp i Feministisk Teori. [What is a woman? And other essays].

Oslo: Gyldendal Norsk Forlag.

Moi, T. (1999a). What is a woman? And other essays. Oxford: Oxford University Press.

Moi, T. (1999b). "I am a woman": The body as background in The second sex. Paroles Gelées, 17 (2), 1-19.

Moi. T. (2002). While we wait: The English translation of The second sex. Signs, 27 (4), 1005-1035. 
Moi, T. (2007). De er ikke alle skabte til at være mødre [They are not all made to become mothers]. Samtiden, 127 (3), 4-19.

Montagu, A. (1956). The biosocial nature of man. New York, NY: Grove Press.

Mudde, A. (2015). Living experiments: Beauvoir, freedom and science. PhaenEx, 10, 57-75.

Malinowski, B. (1930). Parenthood: The basis of social structure. In V. F. Calverton \& S. D. Schmalhausen (Eds.). The new generation: The intimate problems of parents and children (pp. 113-168). New York, NY: Macaulay.

Peňa-Guzmán, D. M. (2016). Beauvoir's reading of biology in The second sex. Journal of French and Francophone Philosophy, 24 (2), 259-285.

Pressnitzer D, C. Suid \& S. Shamma (2011). Auditory Scene Analysis: The Sweet Music of Ambiguity. Frontiers in Human Neuroscience, 5: 158 DOI 10.3389/fncom.2012.00024

Rotkirch, A. (2004). New woman with old feelings? Contrasting Kollontai's and Colette's writings on love. In E. Witt-Brattström (Ed.) The new woman and the aesthetic opening: Unlocking gender in twentieth-century texts (pp. 137-154). Huddinge: Södertörn Academic Studies.

Rotkirch, A. (2007). “All that she wants is another baby?” Longing for children as a fertility incentive of growing importance. Journal of Evolutionary Psychology, 5 (1-4), 89-104.

Rotkirch, A., with Tanskanen, A. O. (2014). The impact of grandparents' investment in mother's fertility intensions in four European Countries. Demographic Research, 31 (1), 1-26.

Rotkirch A., Pettay, J. E., Lahdenpera, M., \& Lummaa, V. (2016). Costly reproductive competitions between coresident females in humans. Behavioral Ecology, 27 (6), 1601-1608.

Roy, D. (2016). Neuroscience and feminist theory: A new direction essay. Signs, 41 (3), 531-552.

Sayers, J. (1982). Biological politics: Feminist and anti-feminist positions. London: Tavistock.

Segerstråle, U. (1992). Sociobiology and feminism: Enemies or allies? In J. M. G. Van der Dennen (Ed.) The nature of the sexes: The sociobiology of sex differences and the battle of the sexes (pp. 221-232). Groeningen: Origin Press.

Segerstråle, U. (2006). An eye on the core: Dawkins and sociobiology. In U. SegerstråleDefenders of Truth and the Sociobiology Debate (pp. 75-94). Oxford: Oxford University Press.

Simons, M. (2003). Bergson's influence on Beauvoir's philosophical methodology. In C. Card (Ed.) The Cambridge companion to Simone de Beauvoir. Cambridge: Cambridge University Press.

Simons, M. (2006). The philosophy of Simone de Beauvoir: Critical essays. Bloomington and Indianapolis: Indiana University Press.

Smuts, B. (1995). The evolutionary origins of patriarchy. Human Nature, 6, 1-32.

Stern, D. N. (1985). The interpersonal world of the infant: A view from psychoanalysis and developmental psychology. New York, NY: Basic Books.

Trivers, R. L. (1985). Social evolution. Mentlo Park, CA: Benjamin Cummins.

Vandermassen, G. (2004). Sexual selection: A tale of male bias and feminist denial. European Journal of Women's Studies, 11 (1), 9-26.

Vandermassen, G. (2005). Who's afraid of Charles Darwin? Debating feminism and evolutionary theory. Lanham, MD: Rowman \& Littlefield.

Vandermassen, G. (2011). Evolution and rape: A feminist Darwinian perspective. Sex Roles, 64, 732-747. 
Zerilli, L. M. G. (1992). A process without a subject: Simone de Beauvoir and Julia Kristeva on maternity. Journal of Women in Culture and Society (Signs), 18 (1), 111-135.

Zuk, M. (1993). Feminism and the study of animal behavior. BioScience, 43, 774-778.

Zuk, M. (2002). Sexual selections: What we can and can't learn about sex from animals. Berkeley, CA: University of California Press.

Zuk, M. (2012). Anthropomorphism: A peculiar institution. The Scientist, 26, 66-67.

\section{Endnotes}

${ }^{1}$ Beauvoir distinguishes analytically between femaleness, femininity and womanhood.
${ }^{2}$ Postmodernists would argue that natural facts only gain significance through non-natural systems of
interpretation. As a moderate constructionist, I would argue that unmediated pathways exist between biological
processes and subjective embodied experiences.
${ }^{3}$ This paper results from a revisiting in 2017 , financially supported by the University of Troms $\varnothing$, of my earlier Darwinist inspired rereading of feminist theorists, including Beauvoir's The Second Sex. This text builds on unpublished outputs of The Norwegian Research Council supported project (2007-2008) "Kroppen som en situasjon: en Darwinistisk lesning av Simone de Beauvoir og Toril Moi. Special consideration goes to former collaborator Anna Rotkirch, Research Professor, Population Research Institute (Väestöliitto) at Helsinki University (Finland) for important insights and substantial contributions to much earlier drafts. Griet Vandermassen, J.P. Roos, Iver Mysterud and Bjørn Vassnes made incisive comments to early texts. Halldis Valestrand and two anonymous colleagues have meticulously commented on this edited, revised and updated text. I would also like to thank scholars at the $16^{\text {th }}$ Simone de Beauvoir Conference at Northumbria University, in June 2008, and the participants at the seminar The Illicit Alliance of Darwin and Feminism (organised by UiT, The Family Federation of Finland and The Christina Institute at the University of Helsinki, in May 2008) for stimulating discussions.

${ }^{4}$ Bleie (2003b) has reviewed the contradictory claims about gender differences in spatial cognition of the two leading cognition researchers Doreen Kimura and Lesley Rogers.

${ }^{5}$ The English translation of Le Deuxième Sexe is notoriously lacking in its translation of terms and arguments (cf. Moi, 2002). I quote the English translation, having consulted the French original and the full-text and muchpraised Swedish translation (Beauvoir, 2002). A new English translation appeared in 2009.

${ }^{6}$ Interpretations of Beauvoir's intentions depend upon the genre of writing upon which she is understood to have mainly relied.

${ }^{7}$ Which theoretical concepts and personal experiences most decisively informed Beauvoir's reasoning about motherhood has been a matter of considerable debate (cf. Fishwick, 2002; Heinämaa, 2003a, 2003b; LundgrenGothlin, 1996; Moi, 1994, 1999a; Simons, 2006).

${ }^{8}$ I like to thank colleague Anna Rotkirch for introducing me to Westermarck's impressive early scholarship.

${ }^{9}$ In What is a Woman?, Moi herself devotes a chapter to the obsolete biologist Brooks, and to Geddes and Thomson, whose works combined biology, zoology and sociology. This may help to explain why Moi does not pursue a critical reassessment of Beauvoir's treatment of obscure Darwinists in The Second Sex.

${ }^{10}$ Modern biology concurs with Beauvoir, noting that the number of chromosomal genes contributed by each gamete is equal and thus of almost equal importance to the future offspring. The egg cell additionally contributes mitochondrial genes and nutrients.

${ }^{11}$ I like to acknowledge Anna Rotkirch for underscoring the importance of Kokko and Jennion's argument.

${ }^{12}$ Beauvoir's understanding of freedom as freedom from reproduction, and therefore that males are more free than females, has been skilfully problematized by Lundgren-Gothlin (1996), MacKenzie (1998) and Moi (1998), among others.

${ }^{13}$ The evolutionary explanation for parent-offspring conflict is that parents may maximize their genetic reproductive success by investing variably in existing and future children. This runs counter to every child's genetic interests to get as much from its parents as possible. The parent-offspring conflict already operates at the foetus level, challenging psychoanalytic notions of mother-child symbiosis, and supporting Beauvoir's view of the maternal body as "invaded" by an alien force (Trivers, 1985). 


\footnotetext{
${ }^{14}$ Moi (1995, p. 178) writes that Beauvoir attributes several exceedingly different meanings to the term ambiguity: ambivalence, distance, separation, fracturing, alienation, contradiction and molestation.

${ }^{15}$ In recent evolutionary literature, considerable attention is given to tool use, the mother-infant bond and social cooperation as prime drivers of larger brain capacity.

${ }^{16}$ In Edelman's seminal works, selectional mechanisms account not only for the workings of the immune system, but also for perception, memory and consciousness (cf. Edelman, 1992, pp. 81-146 and 2006, pp. 2434). Recent contributions by Fernando, Szathmáry, and Husband (2012) on neuro dynamics strengthen Darwinian selection theory.
} 